\title{
Interfaces between Vulnerabilities, Governance, Innovation and Capacity of Response to COVID-19 in Brazilian Northeast
}

\author{
Zoraide Souza Pessoa \\ Rylanneive Leonardo Pontes Teixeira \\ Maria do Livramento Miranda Clementino
}

${ }^{I}$ Department of Public Policy and the Graduate Program in Urban and Regional Studies at the Federal University of Rio Grande Norte (UFRN)

Natal/RN - Brasil

"I Federal University of Rio Grande do Norte (UFRN)

Natal/RN - Brasil

Department of Public Policy and the Graduate Program in Urban and Regional Studies at the Federal University of Rio Grande Norte (UFRN)

Natal/RN - Brasil

\begin{abstract}
Worldwide, the COVID-19 has generated multiple challenges, requiring responses that can effectively make the sustained decline in disease growth levels, and thereby prevent the collapse of health systems. The purpose of this paper is to discuss how the Northeast region of Brazil (NEB) has been building capacity to respond in an innovative and articulated way to the challenges of the pandemic in its territories. This is an essay, based on documentary research and secondary data, collected from state institutional sources and other Brazilian official bodies. The results allow us to conclude that in the NEB these responses are being conducted in an articulated way considering interfaces between social vulnerability, governance and innovation.
\end{abstract}

Keywords: COVID-19; Northeast of Brazil; Vulnerability; Governance; Innovation.

São Paulo. Vol. 23, 2020

Debating ideas

The COVID-19 epoch: Interdisciplinary research towards a new just and sustainable ethics

DOI: http://dx.doi.org/10.1590/1809-4422asoc20200110vu2020L3ID 


\section{INTRODUCTION}

The COVID-19 (Coronavirus Disease 2019), resulting from the new coronavirus (SARS-CoV-2), is officially recognized as a Public Health Emergency of International Importance (PHEII) by the World Health Organization (WHO) on January 30, 2020 (WHO, 2020). A pandemic situation was quickly declared unprecedented on March 11 of the same year (PAHO, 2020). In fact, it is the first time that a coronavirus causes a disease in these dimensions, impacting and altering the global order as never before experienced today.

One of the main challenges generated by COVID-19 is to generate a response capacity that can have an effective impact on the sustained decline in disease growth levels and, thus, prevent the collapse of health systems. Another challenge is to recognize that there are no effective pharmacological responses to date, with non-pharmacological responses being the main initiatives adopted by public managers. These measures are based on social distance between people, restricting the mobility and consumption of territories, especially those that are densely populated, as a means of changing the growth curves of the number of cases and, mainly, of deaths (SHAW; KIM; HUA, 2020; VIEIRA et al., 2020). For this, voluntary participation in maintaining social distance measures and health recommendations is essential.

It is in this context that public managers are immersed, facing a situation never experienced in the world. Thinking about actions to contain, prevent and mitigate the effects of COVID-19 becomes an urgent need, because it has reached more than 5.6 million people, with $30 \%$ of them recovered and more than 350 thousand deaths (HOPKINS, 2020). In Brazil, the numbers are increasing, from 400 thousand infected and more than 25 thousand victims at to date (HOPKINS, 2020).

This paper aims to discuss how the NEB has been building capacity to respond in an innovative and articulated way to the challenges of the pandemic in your territories. It is an essay analysis, based on documentary research and secondary data, collected from state institutional sources and other Brazilian official bodies. The structure of this essay is organized, in addition to this introduction, in three moments: i. COVID-19 in NEB: challenges, vulnerabilities and risks; ii. Response capacity, challenges and innovations to covid-19 in NEB; and iii. Conclusions.

\section{COVID-19 IN NEB: CHALLENGES, VULNERABILITIES AND RISKS}

The fast spread of the new coronavirus in the country brings numerous challenges to the population and public management, not used to dealing with situations such as the pandemic. In Brazil, local transmission began on February 26, with the confirmation of the first case in the state of São Paulo. It quickly reached community contagion, spreading throughout Brazil, with rare cities that do not register cases.

In the case of NEB, the proliferation of the virus continues to increase, making it necessary to contain the contagion of vulnerable populations and those who are at risk. These population groups require special attention, according to studies in countries 
with controlled contamination (SHAW; KIM; HUA, 2020; VIEIRA et al., 2020). It is important to contain progress in children and young people as well, as they are groups with asymptomatic characteristics or milder symptoms.

Given the characteristics of the epidemic crisis, the fragility of the country's public health system is exposed, with the risk of imminent collapse if the speed of spread of the disease is not controlled. In NEB, the collapse is even more imminent due to its high vulnerability, with accentuated asymmetries and inequalities in its social structure, composing a very heterogeneous society with social classes of abysmal amplitudes between rich and poor. The population of this region is 57 million people, $75 \%$ of whom live in urban areas (IBGE, 2019), concentrated especially on its extensive coastal coast, where most of its capitals are located (Figure 1).

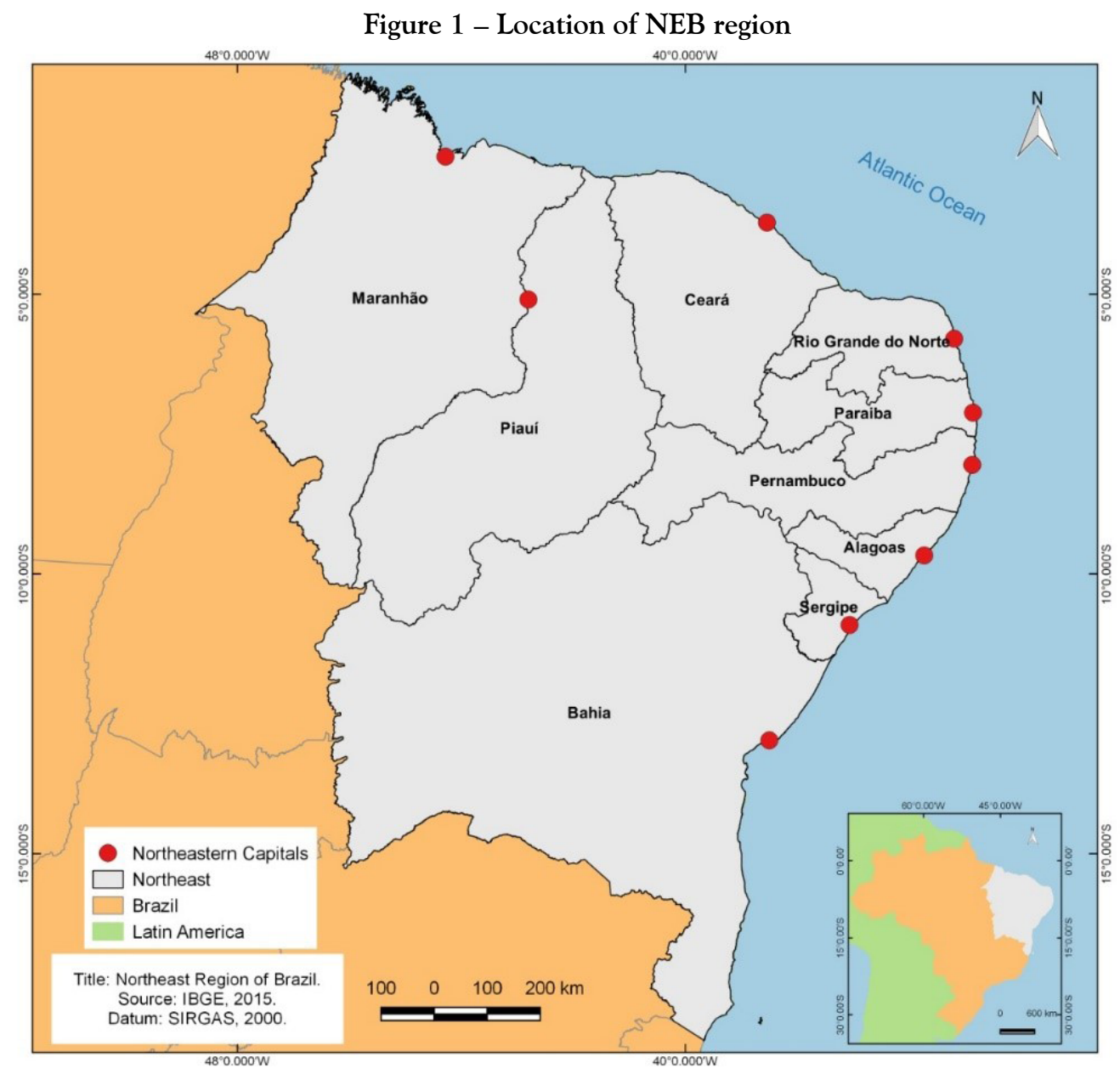

Source: Authors' elaboration based on IBGE data (2015). 
In terms of population characteristics, the NEB has the largest contingent of rural population in the country, adding $27,2 \%$ of the Brazilian population, with 1.794 cities that are equivalent to $32,2 \%$ of the 5.570 Brazilian cities (IBGE, 2010). About $29 \%$ of its inhabitants (16,8 million) live in considered extremely poor cities (CAMPOS; MEIRA, 2020). It is also the region with the highest concentration of vulnerable populations in multiple dimensions, including the spread of the coronavirus based on the Municipal Vulnerability Index to the spread of the Coronavirus (VIC) ${ }^{1}$ developed by the Perseu Abramo Foundation (PAF, 2020). This index aggregates and spatializes sanitary and electrical conditions, demographic density, vulnerable populations, work and income, and disease data that increase the risk of deaths from COVID-19 (Figure 2).

Figure 2 - VIC projection for the Brazilian territory

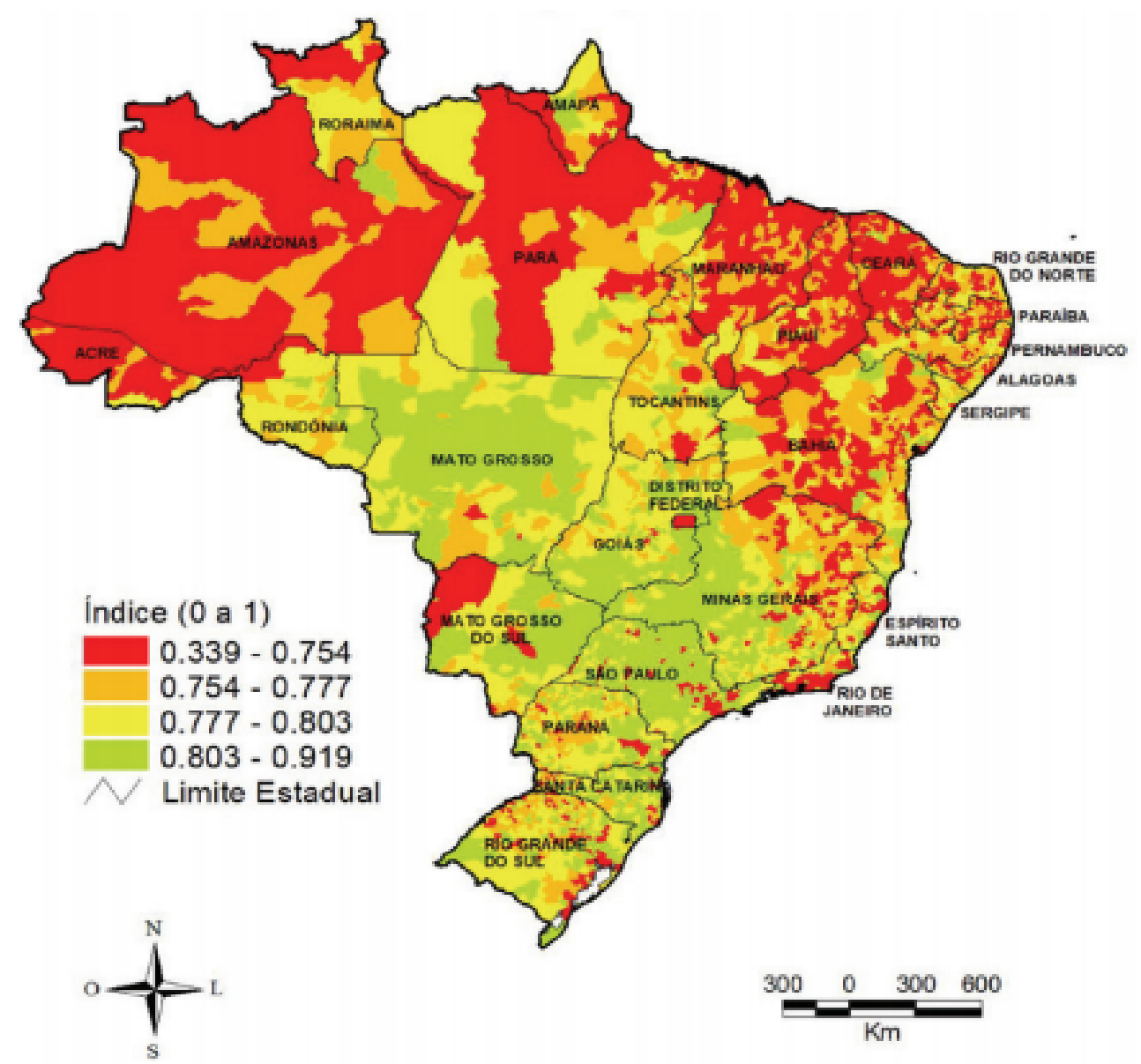

Source: PAF (2020).

1- The VIC was calculated by the FPA, based on the United Nations (UN) Human Development Index (HDI) calculation methodology, with a scale of 0 to 1 , being closer to 1 indicator of better conditions (FPA, 2020). 
Although in recent decades it has made progress in "substantive freedoms" (SEN, 2002) in terms of human development, the NEB presents great weaknesses that are evident in this pandemic moment with the scarcity of public services and health infrastructure. The region has 74 thousand doctors, $82 \%$ of whom are linked to the Unified Health System (UHS), resulting in an average of 1.3 doctors per thousand inhabitants. Although it is within the parameters recommended by the $\mathrm{WHO}$, this distribution is extremely unequal and favors the Metropolitan Regions (MRs) to the detriment of the cities in the interior. Excluding MRs, the average drops to 0.5 doctors per thousand inhabitants (CAMPOS; MEIRA, 2020).

Regarding the health infrastructure required to contain COVID-19, the number of beds in Intensive Care Units (ICUs) in the region is of low availability: only the states of Bahia, Paraíba and Pernambuco are above the national average. Regarding the potential of respirators/ventilators, about a third of northeastern cities (588) have them, representing an average of only 6,8 devices per city (DATASUS, 2019).

In view of this scenario, the pandemic has been affecting the governance capacity of state governments to respond to the growing demand in all states in the region. The confirmed cases so far indicate that there are about $28 \%$ of Brazilian cases in the region, with some states, such as Ceará and Pernambuco, the estimated number of cases per 100 thousand inhabitants already exceeding the national average (Table 1). It is also noteworthy the increasing acceleration in the largest population agglomerations and in the northeastern metropolitan regions, as well as in the interior cities (PESSOA; GRIGIO, 2020).

Table 1 - Total population by situation of COVID-19 cases in NEB (2020)

\begin{tabular}{|c|c|c|c|c|c|c|c|}
\hline \multirow[b]{2}{*}{ Territory } & \multicolumn{2}{|c|}{ Population } & \multicolumn{5}{|c|}{ COVID-19 } \\
\hline & Total & $\begin{array}{c}\text { \% state } \\
\text { pop./ total } \\
\text { pop. }\end{array}$ & Cases & $\begin{array}{c}\% \text { in relation to the } \\
\text { total number of } \\
\text { cases }\end{array}$ & Deaths & $\%$ & $\begin{array}{l}\text { Cases per } \\
100 \text { thousand } \\
\text { inhabitants }\end{array}$ \\
\hline Brazil & 210.147 .125 & ... & 142.936 & .. & 9268 & ... & 67,5 \\
\hline Nordeste & 57.071 .654 & 27,2 & 45.257 & 31,7 & 2590 & 27,9 & 79,3 \\
\hline Bahia & 14.873 .064 & 26,1 & 4.745 & 10,5 & 165 & 6,4 & 31,9 \\
\hline Pernambuco & 9.557 .071 & 16,7 & 11.587 & 25,6 & 845 & 32,6 & 121,2 \\
\hline Ceará & 9.132 .078 & 16,0 & 15.134 & 33,4 & 903 & 34,9 & 165,7 \\
\hline Maranhão & 7.075 .181 & 12,4 & 5.909 & 13,1 & 330 & 12,7 & 83,5 \\
\hline Paraíba & 4.018 .127 & 7,0 & 1.849 & 4,1 & 111 & 4,3 & 46,0 \\
\hline Rio Grande do & 3.506 .853 & 6,1 & 1.821 & 4,0 & 76 & 2,9 & 51,9 \\
\hline Alagoas & 3.337 .357 & 5,8 & 1.867 & 4,1 & 98 & 3,8 & 55,9 \\
\hline Piauí & 3.273 .227 & 5,7 & 1.131 & 2,5 & 37 & 1,4 & 34,6 \\
\hline Sergipe & 2.298 .696 & 4,0 & 1.214 & 2,7 & 25 & 1,0 & 52,8 \\
\hline
\end{tabular}

Source: Authors' elaboration based on data from IBGE - Estimates of the population resident in Brazil (2019), Brazil Ministry of Health (2020), and Fiocruz-CIDACs and UFBA (2020). CoVida Network Panel. Cases until May 8, 2020. 
The possibility of responding to the effects of COVID-19, in the face of the need for quick and innovative initiatives, also poses challenges and difficulties in the face of such adverse social realities.

\section{RESPONSE CAPACITY, CHALLENGES AND INNOVATIONS TO COVID-19 IN NEB}

Faced of the scenario of vulnerabilities and inequalities intrinsic to their reality, the nine states of NEB initiated actions to confront COVID-19 in March. Effectively, these actions started after the decree of the Public Health Emergency situation of National Interest (PHENI) in the country on February 3, 2020 by the Ministry of Health through Ordinance 188, which defined the guidelines of the National Contingency Plan for Infection Human by the new Coronavirus (COVID-19). This plan guides states and cities to carry out their contingency plans in accordance with the response levels required by the WHO International Health Regulations (IHR) (Box 1).

\section{Box 1 - Response levels of the National Contingency Plan for Human In- fection with the new Coronavirus COVID-19, Brazil (2020)}

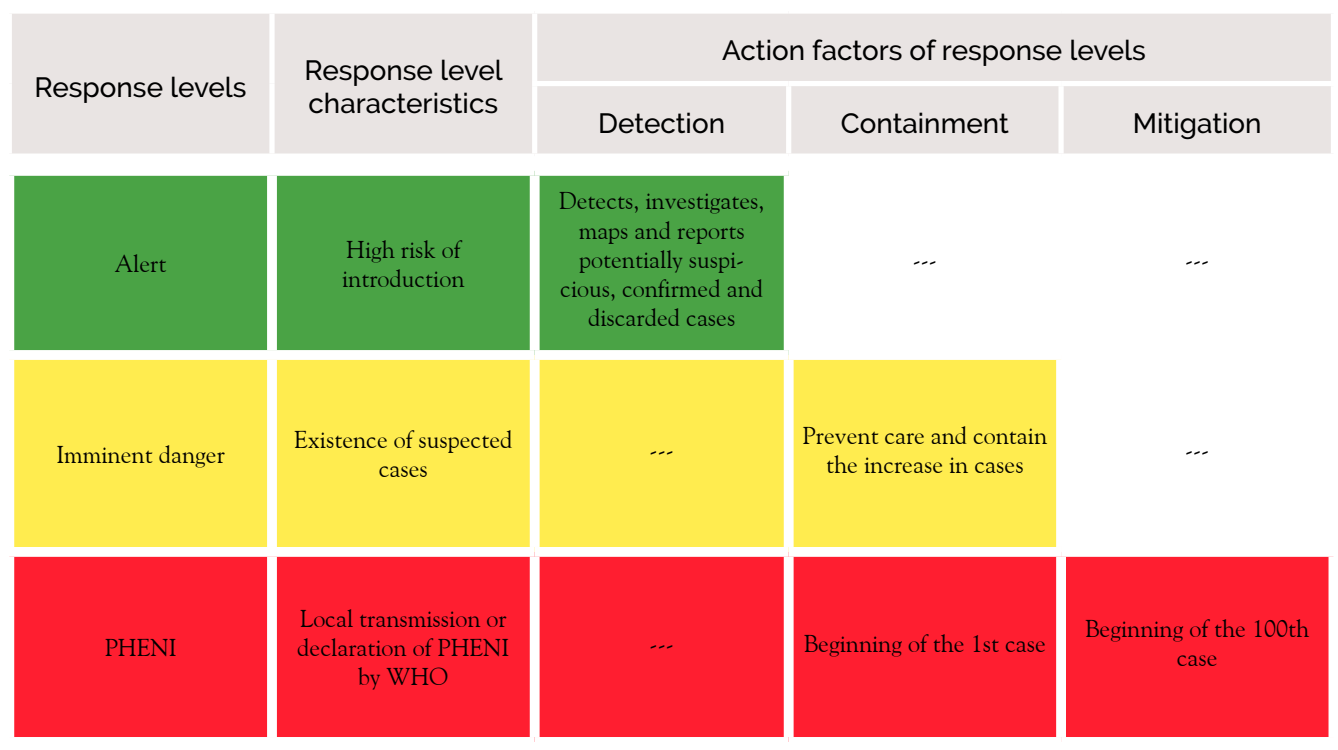

Source: Authors' elaboration based on Brazil (2020)

The states started their actions already at the maximum response level, jumping the alert and imminent danger levels, thus starting to act in the mitigation phase effectively on March 12 when the country reached 100 confirmed cases (FIOCRUZ-CIDACS; UFBA, 2020). The coping actions were the disclosure of their contingency plans, the enactment of a state of emergency and the adoption of the first measures of social distance.

In addition, in an attempt to share initiatives that could have a greater impact 
on their individual contingency actions and, at the same time, generate an impact in a more effective, integrated and regional manner, NEB governors decided to act in the face of the pandemic through the Interstate Consortium of Sustainable Development of the Northeast (Northeast Consortium). Created in 2019, the Consortium is configured in an innovative mechanism of public management, but also of support and political strength in the bargaining of financial resources with the current federal government that publicly acts in a different way to NEB, perhaps as a reflection of the low electoral performance obtained.

Under the character of unprecedented since it is the first among Brazilian states, the Consortium can act by minimizing bureaucracies and barriers between state governments enabling proactive and collaborative action between government entities, and promoting a synergistic effect in the implementation of public policies (CLEMENTINO, 2019). In addition, also offers governments a means of sharing horizontal and vertical resources with other government agencies, maintaining state autonomy, strengthening their individual capacity to act (CLEMENTINO, 2019).

In the context of COVID-19, the formation of regional and local governance capacities is essential for their confrontation, as demonstrated by international experiences (SHAW; KIM; HUA, 2020). Beginning prior to the current crisis, the alignment fostered by the Consortium already shows concrete results in the management of COVID-19 with the strategic adoption of social distance measures, initiated by all states in the middle of the second half of March 2020.

The Consortium strategies take place in a collegial manner, officially pronounced through the disclosure of Letters, under the current presidency of the Governor of Bahia. So far, five Letters have been released, supported in accordance with recommendations from WHO and public health agencies and the Brazilian scientific academy. The Letters, published on the Consortium social networks, defend social distance as "pro-life" measures and balance between life and the economy (NORTHEAST CONSORTIUM, 2020).

As a mechanism to contain the pandemic, the Consortium undertook other initiatives, notably: i. the collective purchase of medicines, hospital supplies and mechanical respirators; ii. the sending of a letter to the Chinese ambassador in Brazil, requesting assistance with medical and hospital supplies; and iii. the creation of the Scientific Committee to Combat Coronavirus (C4NE) ad hoc, composed of notable national experts for advising the Consortium and monitoring the pandemic.

The C4NE, created in April 2020, is one of the most important initiatives of the Consortium. It acts by indicating several scientific recommendations to help governors' decision-making in their responses to COVID-19. It is important to highlight this initiative, because at the national level it does not exist, although it is a recommendation of the national contingency plan. At the international level, this initiative has already been implemented by other countries (MOATTI, 2020).

The C4NE recommendations (2020) are based on ten axes (Box 2) and disseminated through bulletins. Among the recommendations, social distancing measures stand out as a strategy to curb the contagion growth curve in the region, especially because 
some NEB states, such as Ceará, Maranhão and Pernambuco, already indicate saturation of their health systems, showing signs collapse. In these three states, the lockdown has started, that is, the total and controlled social distance. It should certainly be adopted by the other NEB governments, but C4NE's recommendations are that it should occur in a planned manner. Through the C4NE, the Monitora COVID $-19^{2}$ application is being made available, telemedicine platform for the entire NEB population to map information about the disease.

All the initiatives highlighted, especially the constitution of C4NE, are a relief in the face of helplessness at the federal level. In this context, the strategies remain without clear definitions to curb the growth of COVID-19 in the country. Especially due to the fact that the President of the Republic as the President of the Republic maintains the discourse of minimizing the pandemic, acting in conflicts with his ministers of health, governors and institutions across the country (RODRIGUES; AZEVEDO, 2020) and against the world (THE LANCET, 2020).

Box 2 - Axes of C4NE recommendations (2020)

\begin{tabular}{|c|c|}
\hline \multirow{5}{*}{ SOCIAL DISTANCING } & Restrict non-essential activities \\
\hline & Hand wash \\
\hline & Maintain a distance of 2 meters between people \\
\hline & Use face masks \\
\hline & Prohibit agglomerations \\
\hline RESIDENTIAL ISOLATION & $\begin{array}{c}\text { Isolate suspected cases with mild or traveling symptoms } \\
\text { (14-day quarantine) }\end{array}$ \\
\hline \multirow{3}{*}{$\begin{array}{l}\text { FLEXIBILIZATION OF SOCIAL DISTANCING } \\
\text { MEASURES }\end{array}$} & Not recommended with increasing contagion curve \\
\hline & Consider if there is a retreat of more than 14 days \\
\hline & At the moment it is not recommended for any NEB state \\
\hline \multirow{3}{*}{ LOCKDOWN } & Decree if $80 \%$ of the ICU beds are occupied \\
\hline & Define bases for planning, control and monitoring \\
\hline & Can be done sectorally and regionally \\
\hline \multirow{4}{*}{ SPACE MOBILITY } & Import control of cases by air and land \\
\hline & Restrict non-essential road traffic on state highways \\
\hline & Disinfect public places \\
\hline & Interm control intercity traffic \\
\hline REGIONAL/LOCAL INTEGRATION & $\begin{array}{l}\text { Articulate state and municipal secretariats and between } \\
\text { NEB states }\end{array}$ \\
\hline
\end{tabular}




\begin{tabular}{|c|c|}
\hline \multirow{8}{*}{ HEALTH } & $\begin{array}{l}\text { Restricting use of drugs without safe scientific evidence at any } \\
\text { stage of the disease }\end{array}$ \\
\hline & $\begin{array}{l}\text { Create Emergency Health Brigade of Brazilian doctors trained } \\
\text { abroad and revalidate their diplomas }\end{array}$ \\
\hline & $\begin{array}{l}\text { Expand the protection of health teams by increasing the supplies } \\
\text { of PPE }\end{array}$ \\
\hline & Direct PCR testing to key professionals \\
\hline & $\begin{array}{l}\text { Sharing respirators between two patients with the same pulmo- } \\
\text { nary clinical conditions }\end{array}$ \\
\hline & Emergency room ventilators use \\
\hline & Hire intensive care doctors \\
\hline & Increase bed spaces \\
\hline \multirow{3}{*}{ SCIENCE } & Articulate different scientific areas of NEB \\
\hline & $\begin{array}{c}\text { Create } 9 \text { thematic subcommittees to assist with scientific } \\
\text { recommendations }\end{array}$ \\
\hline & Create support network of national and international scientists \\
\hline \multirow{2}{*}{ TECHNOLOGY } & Use digital displacement monitoring technologies \\
\hline & Promote telemedicine by Monitora COVID-19 \\
\hline \multirow{2}{*}{ SOCIAL AND ECONOMY } & Mitigate the social effects of the pandemic \\
\hline & Stimulating local and regional microeconomics \\
\hline
\end{tabular}

Source: Authors' elaboration based on C4NE (2020).

In summary, the initiatives undertaken in the NEB region, through their governors, innovate with the perspective of regional integration via collective action as a strategy that can mitigate the effects of the pandemic on the health systems of the states that already had a deficit.

All the strategies implemented by the Consortium demonstrate that shared actions are an asset in the "war" against the virus. This collaboration could be the differential in facing one of the biggest disadvantages of this health crisis: its impacts unevenly distributed in Brazil. The Consortium originality, which previously pointed out factors favorable to its success (CLEMENTINO, 2019), is now one of the region's main protagonist assets in crisis management (CLEMENTINO et al., 2020).

\section{CONCLUSIONS}

The concern of NEB state governments with the vulnerability to COVID-19 in the region is notorious. It corroborates for this situation its urban dynamics which generates a complex network of cities and metropolitan areas, with high demographic densities and located, mainly, in capitals and metropolitan areas. In addition, they are also allied with other dense and interiorized urban agglomerations distributed throughout its territory. These urban agglomerations would feel the collapse of their health systems more strongly and quickly (PESSOA; TEIXEIRA, 2020). On the other side, the majority of families, both in the urban peripheries and in the rural area, depend on assistance policies, reveal- 
ing an even more serious social situation in a situation like the current one.

However, in light of international initiatives in terms of governance of the crisis generated by the new coronavirus, it is categorical that responses should be oriented at the local level and integrated between the different spheres of government in a given country. They must be based on the execution of shared and consensual actions in the implementation of rigid models of non-pharmacological actions (VIEIRA et al., 2020). They must also be anchored in scientific, technological and participatory approaches (SHAW; KIM; HUA, 2020). It is only with these pillars that it is possible to avoid catastrophes due to the difficulty in adequately responding to the clinical treatment of this complex disease, whose levels of recovery of those infected are delayed (SOHRABI et al., 2020). This delay occurs because the disease affects several organ systems individually or simultaneously (WADMAN et al., 2020).

The adoption of social distance by the Consortium governors can be the most effective way to respond to the uncertainties that individual NEB states face due to the condition of poorly sustained development that characterizes them. Linked to this, there is the absence of crisis management at the national level of articulated command at all levels of government management and based on solid proposals for actions based on participatory local governance networks.

In the absence of these conditions, it remains for NEB to seek innovation capacity based on its own regional integration and, thus, consolidate an effective mechanism of innovative articulation for the mitigation of COVID-19 in its territory.

\section{References}

BRAZIL - Ministry of Health. Plano de Contingência Nacional para Infecção Humana pelo novo Coronavírus COVID-19. Brasília: Ministry of Health, 2020. Adapted by the authors. Available on: https:/portalarquivos.saude.gov.br/images/pdf/2020/marco/25/Livreto-Plano-de-Contingencia-5-Corona2020-210x297-16mar.pdf. Accessed on: March 20, 2020.

CAMPOS, Jarvis; MEIRA, Karina Cardoso. A interiorização da Covid-19 no Nordeste: temos infraestrutura de saúde?. Natal (RN): PPGDem/UFRN, April 04, 2020. Available on: https:// demografiaufrn.net/2020/04/04/a-interiorizacao-da-covid-19-no-nordeste-temos-infraestrutura-de-saude/. Accessed on: May 06, 2020.

ClEMENTINO, M. do L. M. A Atualidade e o ineditismo do Consórcio Nordeste. 2019. Boletim Regional, Urbano e Ambiental (IPEA), v. 21, p. 165-175, 2019. Available on: http:// repositorio.ipea.gov.br/handle/11058/9702? mode=full. Accessed on: March 05, 2020.

CLEMENTINO, M. do L. M.; QUEIROZ, J. V. R. de; ALMEIDA, Lindijane de S. B.; SILVEIRA, R. M. da C.; CAMARA, R. L. M. da; SILVA, B. C. do N. A colaboração em tempos de pandemia e o protagonismo do Consórcio Nordeste. Rio de Janeiro: Boletim Semanal do Observatório das Metrópoles, May 07, 2020. Available on: https://www.observatoriodasmetropoles. net.br/a-colaboracao-em-tempos-de-pandemia-e-o-protagonismo-do-consorcio-nordeste/. 
Accessed on: May 07, 2020.

C4NE. Comitê Científico de Combate ao Coronavírus (C4NE). Consórcio Nordeste: 2020. Available on: https://www.comitecientifico-ne.com.br/. Accessed on: May 05, 2020.

DATASUS - Ministry of Health. Cadastro Nacional de Estabelecimentos de Saúde (CNES). DATASUS: Health Information, Data from May 05, 2020. Available on: http://tabnet.datasus. gov.br/cgi/cnes/NT_RecursosF\%C3\%ADsicos.htm. Accessed on: May 05, 2020.

FELIZARDO, Nayara. CORONAVÍRUS: MÉDICOS DE PERNAMBUCO CRIAM SISTEMA DE PONTOS PARA ESCOLHER QUEM TERÁ VAGA EM UTI. The Intercept Brazil, April 29, 2020. Available on: https://theintercept.com/2020/04/29/coronavirus-sistema-pontos-pernambuco-colapso/?fbclid=IwAR1fRmqSKdXcjEurLGaWDIC_RaWa58wHR06b7xN-SGwdCiy4fcKW4WdwxEc. Accessed on: April 29, 2020.

FIOCRUZ-CIDACS; UFBA. Painel da Rede CoVida. Salvador: UFBA, April 16, 2020. Available on: https://painel.covid19br.org/. Accessed on: April 28, 2020.

HOPKINS, J. COVID-19 Dashboard by the Center for Systems Science and Engineering (CSSE) at Johns Hopkins University (JHU). Baltimore: Johns Hopkins University, 2020. Available on: https://coronavirus.jhu.edu/map.html. Accessed on: May 27, 2020.

IBGE - Instituto Brasileiro de Geografia e Estatística. Censo Demográfico 2010. Brasília: IBGE, 2010. Available on: https://censo2010.ibge.gov.br/. Accessed on: April 21, 2020.

IBGE - Instituto Brasileiro de Geografia e Estatística. Geociências. Brasília: IBGE, 2015. Available on: https://www.ibge.gov.br/geociencias/downloads-geociencias.html. Accessed on: April 27, 2020.

IBGE - Instituto Brasileiro de Geografia e Estatística. Aspectos Demográficos - Informações Gerais. Brasília: IBGE, 2019. Available on: https://www.ibge.gov.br/. Accessed on: April 29, 2020.

MOATTI, Jean-Paul. The French response to COVID-19: intrinsic difficulties at the interface of science, public health, and policy. The Lancet Public Health, v. 5, n. 5, p. 255, 2020. Available on: https://doi.org/10.1016/S2468-2667(20)30087-6. Accessed on: May 03, 2020.

NORTHEAST CONSORTIUM. O Brasil que mais cresce está no Nordeste. 2020. Available on: https://consorcionordeste.com/. Accessed on: May 05, 2020.

PAHO - PAN AMERICAN HEALTH ORGANIZATION. Folha informativa - COVID-19 (doença causada pelo novo coronavírus). Washington: PAHO, 2020. Available on: https://www. paho.org/bra/index.php?option $=$ com_content\&view $=$ article\&id $=6101$ : covid $19 \&$ Itemid $=875$. Accessed on: April 28, 2020.

PERSEU ABRAMO FOUNDATION - PAF. Boletins FPA: Estudo ranqueia municípios mais vulneráveis ao coronavírus. FPA: 2020. Available on: https:/fpabramo.org.br/2020/04/16/estudo-ranqueia-municipios-mais-vulneraveis-ao-coronavirus/. Accessed on: April 16, 2020.

PESSOA, Zoraide Souza; GRIGIO, Alfredo Marcelo. As cidades médias no contexto da pandemia de COVID-19: o caso de Mossoró (RN). Núcleo de Estudos de Política Local (NEPOL), 
April 17, 2020. Available on: https://nepolufjf.wordpress.com/2020/04/17/as-cidades-medias-no-contexto-da-pandemia-de-covid-19-o-caso-de-mossoro-rn/?fbclid=IwAR21THkW020tTaG0Ewph83DzMD5gLcyXm56mqd92eOA6mQ-MJYPA8MCYNQk\%22\%20https://nepolufjf. wordpress.com/2020/04/17/as-cidades-medias-no-contexto-da-pandemia-de-covid-19-o- caso-de-mossoro-rn/?fbclid=IwAR21THkW020tTaG0Ewph83DzMD5gLcyXm56mqd92eOA6mQ-MJYPA8MCYNQk. Accessed on: May 02, 2020.

PESSOA, Zoraide Souza; TEIXEIRA, Rylanneive Leonardo Pontes. Vulnerabilidades e sociedade de riscos em tempos de COVID-19. Rio de Janeiro: Boletim Semanal do Observatório das Metrópoles, May 14, 2020. Available on: h https://www.google.com/ search?q=ttps $\% 3 \mathrm{~A} \% 2 \mathrm{~F} \% 2 \mathrm{Fwww} . o b s e r v a t o r i o d a s m e t r o p o l e s . n e t . b r \% 2 F v u l n e r a b i l i d a d e s-$ -e-sociedade-de-riscos-em-tempos-de-covid-19\%2F\&rlz=1C1CHZL_pt-BRBR740BR740\&oq =ttps\%3A\%2F\%2Fwww.observatoriodasmetropoles.net. br\%2Fvulnerabilidades-e-sociedade-de-riscos-em-tempos-de-covid-19\%2F\&aqs = chrome..69i5 7j69i58.359j0j4\&sourceid $=$ chrome\&ie $=U$ TF-8. Accessed on: May 27, 2020.

RODRIGUES, Juliana Nunes; AZEVEDO, Daniel Abreu de. Pandemia do Coronavírus e (des) coordenação federativa: evidências de um conflito político-territorial. Espaço e Economia [Online], 18 | 2020. Available on: https://doi.org/10.4000/espacoeconomia.12282. Accessed on: May 07, 2020.

SEN, Amartya. Desenvolvimento como liberdade. São Paulo: Companhia das Letras, 2002.

SHAW, Rajib; KIM, Yong-kyun; HUA, Jinling. Governance, technology and citizen behavior in pandemic: Lessons from COVID-19 in East Asia. Progress in Disaster Science, v. 6, n. 100090, April 2020. Available on: https://doi.org/10.1016/j.pdisas.2020.100090. Accessed on: April 27, 2020.

SOHRABI, Catrin; ALSAFI, Zaid; O’NEILL, Niahm; KHAN, Mehdi; KERWAN, Ahmed; JABIR, Ahmed; LOSIFIDIS, Christos; AGHA, Riaz. World Health Organization declares global emergency: A review of the 2019 novel coronavirus (COVID-19). International Journal of Surgery, v. 76, April 2020, p. 71-76. Available on: https://doi.org/10.1016/j.ijsu.2020.02.034. Accessed on: May 08, 2020.

THE LANCET. COVID-19 in Brazil: “So what?". The Lancet Public Health, v. 395, p. 1461, 2020. Available on: https://doi.org/10.1016/S0140-6736(20)31095-3. Accessed on: May 10, 2020.

VIEIRA, Cristina Mesa; FRANCO, Oscar H.; RESTREPO, Carlos Gómez; ABEL, Thomas. COVID-19: The forgotten priorities of the pandemic. Maturitas, v. 136, p. 38-41, 2020. Available on: https://doi.org/10.1016/j.maturitas.2020.04.004. Accessed on: April 21, 2020.

WADMAN, Meredith; COUZIN-FRANKEL, Jennifer; KAISER, Jocelyn; MATACIC, Catherine. A rampage through the body. Science, v. 368, p. 356-360, 2020. Available on: https://doi. org/10.1126/science.368.6489.356. Accessed on: April 10, 2020.

WHO - WORLD HEALTH ORGANIZATION. Director-General's statement on IHR Emergency Committee on Novel Coronavirus (2019-nCoV). Genebra: WHO, 2020. Available on: https://www.who.int/dg/speeches/detail/who-director-general-s-statement-on-ihr-emergency-committee-on-novel-coronavirus-(2019-ncov). Accessed on: April 20, 2020. 


\section{Zoraide Souza Pessoa}

$\square$ zoraidesp@gmail.com

ORCiD: https://orcid.org/0000-0002-9509-5027

\section{Rylanneive Leonardo Pontes Teixeira}

$\square$ pontesrylanneive@gmail.com

ORCiD: https://orcid.org/0000-0001-8635-3234

\section{Maria do Livramento Miranda Clementino}

$\square$ mlmclementino@gmail.com

ORCiD: https://orcid.org/0000-0001-7972-4869
Submitted on: $27 / 05 / 2020$ Accepted on: 29/05/2020

2020;23:e0110

How to cite: PESSOA, Z. S.; TEIXEIRA, R. L. P.; CLEMENTINO, M. L. M. Interfaces Between Vulnerabilities, Governance, Innovation and Capacity of Response to COVID-19 in Brazilian Northeast. Ambiente \& Sociedade. São Paulo, v. 23, p. 1-13, 2020. 


\title{
Interfaces entre Vulnerabilidades, Governança, Inovação e Capacidade de Resposta à COVID-19 no Nordeste Brasileiro
}

\author{
Zoraide Souza Pessoa \\ Rylanneive Leonardo Pontes Teixeira \\ Maria do Livramento Miranda Clementino
}

São Paulo. Vol. 23, 2020

Ideias em debate

A época $\mathrm{CO}$.

VID-19: Pesquisa interdisciplinar $\mathrm{e}$ uma nova ética sustentável e justa
Resumo: Mundialmente, a COVID-19 tem gerado múltiplos desafios, exigindo respostas que possam efetivamente fazer o recuo sustentado dos níveis de crescimento da doença e, assim, evitar o colapso dos sistemas de saúde. O objetivo deste artigo é discutir como a região Nordeste do Brasil (NEB) vem construindo capacidade de resposta de forma inovadora e articulada aos desafios da pandemia em seus territórios. Trata-se de um ensaio, com base em pesquisa documental e dados secundários, coletados em fontes institucionais estaduais e demais órgãos oficiais brasileiros. Os resultados nos permitem concluir que no NEB essas respostas estão sendo conduzidas de modo articulado considerando interfaces entre vulnerabilidade social, governança e inovação.

Palavras-chave: COVID-19; Nordeste do Brasil; Vulnerabilidade; Governança; Inovação.

Como citar: PESSOA, Z. S.; TEIXEIRA, R. L. P.; CLEMENTINO, M. L. M. Interfaces entre Vulnerabilidades, Governança, Inovação e Capacidade de Resposta à COVID-19 no Nordeste Brasileiro. Ambiente $\mathbb{E}$ Sociedade. São Paulo, v. 23, p. 1-13, 2020. 


\title{
Interfaces entre Vulnerabilidad, Gobierno, Innovación y Capacidad de Respuesta a la COVID-19 en el Noreste de Brasil
}

\author{
Zoraide Souza Pessoa \\ Rylanneive Leonardo Pontes Teixeira \\ Maria do Livramento Miranda Clementino
}

São Paulo. Vol. 23, 2020

Ideas en debate

La época CO.

VID-19: investigación interdisciplinaria y una nueva ética sostenible y justa
Resumen: En todo el mundo, la COVID-19 ha generado múltiples desafíos, requiriendo respuestas que efectivamente pueden hacer que la disminución sostenida en los niveles de crecimiento de la enfermedad y, así, eviten el colapso de los sistemas de salud. El propósito de este artículo es discutir cómo la región Nordeste de Brasil (NEB) ha estado creando capacidad para responder de manera innovadora y articulada a los desafíos de la pandemia en sus territorios. Este es un ensayo, basado en investigación documental y datos secundarios, recopilados de fuentes institucionales estatales y otros organismos oficiales brasileños. Los resultados nos permiten concluir que en NEB estas respuestas se llevan a cabo de manera articulada considerando las interfaces entre vulnerabilidad social, gobernanza e innovación.

Palabras clave: COVID-19; Nordeste del Brasil; Vulnerabilidad; Gobernanza; Innovación.

Como citar: PESSOA, Z. S.; TEIXEIRA, R. L. P.; CLEMENTINO, M. L. M. Interfaces entre Vulnerabilidades, Gobernanza, Innovación y Capacidad de Respuesta al COVID-19 en el Noreste del Brasil. Ambiente \& Sociedade. São Paulo, v. 23, p. 1-13, 2020. 